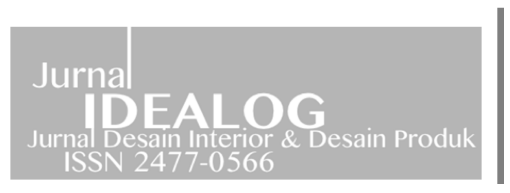

Jurnal I D E A L O G

Jurnal Desain Interior \& Desain Produk

Vol.1 No.1, April 2016

ISSN 2477 - 0566

\author{
Rizka Rachmawati \\ Program Studi Desain Interior \\ Universitas Telkom \\ rizkarach@tcis.telkomuniversity.ac.id
}

\title{
Gaya Hidup dan Restoran Jepang Studi Kasus pada Interior Restoran Sushi Tei Bandung
}

\begin{abstract}
Abstrak: Gaya hidup ada berdasarkan fenomena yang terjadi pada pribadi manusia ketika memenuhi nilai lebih dari sekedar kebutuhan. Pola gaya hidup manusia secara global lebih mudah terlihat bila direpresentasikan dalam bentuk desain pada ruang public, salah satunya di dalam restoran. Restoran merupakan fasilitas ruang publik yang bersifat memberikan suasana santai, ramah, dan berguna sebagai sarana yang menyediakan kebutuhan makan. Arti makan sendiri kini bukan sekedar alat penyambung hidup, tetapi lebih kepada sebuah alat aktualisasi diri. Berdasarkan hal tersebut, maka interior restoran menjadi salah satu area publik yang berperan dalam merepresentasikan sifat gaya hidup, karena aktivitas di dalam restoran yang kini telah bergeser sebagai wadah penangkap citra diri melalui berbagai kegiatan yang dilakukan selain makan. Salah satu studi kasus yang akan dibahas yaitu restoran Jepang. Saat ini restoran tersebut telah berhasil menciptakan tren di kalangan masyarakat luas. Hal ini tentunya berkaitan dengan kesesuaian dan keunikan yang ditimbulkan oleh restoran dengan gaya hidup masyarakat sekitarnya. Penelitian ini bertujuan untuk mengidentifikasi ada tidaknya pengaruh gaya hidup yang diterapkan pada restoran Jepang, sehingga berhasil menarik pengunjung dan memunculkan tren gaya hidup. Topik ini dibahas menggunakan metode kualitatif dengan pendekatan observasi, wawancara, survey, dan juga studi literatur. Dengan adanya penelitian tersebut, desainer interior diharapkan dapat memanfaatkan pola gaya hidup masyarakat sebagai faktor penting yang mempengaruhi bentukan elemen interior sebuah restoran Jepang.
\end{abstract}

Kata kunci: gaya hidup, konsumsi, interior, restoran Jepang, tren

\begin{abstract}
Lifestyle exists based on the phenomenon that occurs in human life as the act of consumption. This act is an expression to meet the value which is more than just a necessity. The human lifestyle can be more easily observed when represented in the design of public place. One of the public space that can be discussed is the restaurant. Restaurants in this case is a facility that provides a relaxed and friendly atmosphere, and also useful as a means of providing meals. Meal itself is now not just a means of subsistence, but also selfactualization. Thus, the interior design of the restaurant plays a role in representing the nature of the lifestyle. One of the case studies to be discussed here is a Japanese restaurant. Nowadays, the restaurant has managed to create a trend in the community. This is certainly related to uniqueness of the restaurant and its suitability with the lifestyle of the surrounding community. This study aimed to identify whether there is the influence of lifestyle that is applied to a Japanese restaurant, so it managed to attract visitors and create lifestyle trends. This topic is discussed using qualitative methods, such as observation, interviews, surveys, and also literature study. Given the study, interior designers are expected to take advantage of people's lifestyle patterns as an important factor that affects the formation of elements of the interior of a Japanese restaurant.
\end{abstract}

Keywords: lifestyle, interior design, Japanese restaurant, trend 


\section{Pendahuluan}

Manusia perlu menyesuaikan antara taraf hidup dengan budayanya. Budaya atau gaya hidup sendiri dapat dikatakan sebagai sebuah resistensi yang sangat menunjang kelangsungan interaksi manusia agar dapat menyesuaikan diri dengan lingkungan sekitarnya,dalam hal ini konteks yang dijadikan contoh adalah ruang publik. Karena ruang publik bersifat umum dan siapapun dapat mengunjungi serta menikmati suasana apa yang tercipta di dalamnya. Salah satu ruang publik yang dapat dibahas adalah restoran.

Restoran dalam hal ini adalah fasilitas ruang publik yang lebih bersifat memberikan suasana santai, ramah, dan berguna sebagai sarana yang menyediakan kebutuhan kuliner. Tuntutan gaya hidup manusia yang saat ini serba disibukan dengan kegiatan yang membuat waktu terasa lebih cepat membuat sarana peristirahatan sangat dibutuhkan. Selain untuk melepas rasa lapar dan dahaga, sarana publik restoran atau cafe berguna untuk memenuhi keperluan gaya hidup seperti makan atau sekedar mengobrol menghabiskan waktu bersama kerabat.

Dalam konteks pusat perbelanjaan, area yang paling sering dikunjungi adalah area peristirahatan seperti food court, restoran, atau cafe. Hal tersebut dapat terjadi karena siapapun dapat secara bebas bersantai dan melepas lelah sembari menikmati hidangan yang disediakan. Fasilitas restoran atau area makan pun lebih terasa akrab dan memiliki pelayanan yang lebih baik dibanding dengan area pertokoan atau area publik lainnya. Pengunjung pun dapat duduk berlama-lama tanpa perlu khawatir teritorialnya terganggu.

Kenyataan diatas menunjukkan perlunya kesesuaian desain yang diterapkan antara area vital pada ruang publik dengan gaya hidup pengunjungnya. Kesesuaian tersebut penting untuk diperhatikan guna menciptakan suasana yang benar-benar nyaman bagi pengunjung. Tak hanya hal tersebut, elemen desain yang terdapat pada area vital dalam hal ini area makan sebisa mungkin dapat menciptakan kesan tersendiri bagi pengunjung. Sehingga secara tak langsung citra restoran tersebut dapat benar-benar melekat dengan situasi pengunjung yang berada di dalamnya.

Fenomena masyarakat yang gemar mengunjungi restoran guna menikmati waktu bersantai inilah yang akan dibahas pada uraian selanjutnya. Salah satu contoh kasus yang diambil adalah restoran Jepang yang memiliki keunikan baik dari segi cita rasa, cara pelayanan, sajian suasana, yang diwarnai dengan kebudayaan Jepang maupun image yang dihadirkannya.

Ruang lingkup yang menjadi permasalahan yaitu pada jaman sekarang ini mengkonsumsi makanan bukan lagi hanya sekedar untuk memenuhi kebutuhan, namun lebih dijadikan gaya hidup. Bila dibandingkan dengan masa beberapa dekade yang lalu, bersantap sehari-hari cenderung dilakukan di rumah dimana makanan yang disajikan hasil masak sendiri. Pada masa kini, dengan kesibukan luar biasa masing-masing para anggota keluarga, acara makan kerap dilakukan sendiri sendiri dan jarang dilakukan di rumah. Hal tersebut memang telah menjadi fenomena gaya hidup di era teknologi yang serba maju saat ini. Bersantai di restoran juga menjadi ajang untuk berkumpul dan bersosialisasi. Acara-acara reuni, pertemuan dan bahkan sekedar berkumpul dengan kolega juga sering diadakan di restoran pada jam-jam santap siang dan malam. Rentan waktu yang dibutuhkan untuk berada di area tersebut juga sangat lama. Situasi lingkungan yang diterapkan tentunya harus 
menunjang kenyamanan pengunjung.karena itu dibangun fasilitas pendukung di luar kepentingan kuliner, seperti fasilitas sarana duduk seperti sofa, hotspot atau internet wireless, sirkulasi udara yang nyaman, dll. Hal itu semata-mata diimplementasikan dalam desain guna menjaga pengunjung agar betah dan dapat relax menikmati suasana sekitar.

Kegiatan pengunjung di restoran inilah yang dapat digunakan desainer sebagai peluang dalam penerapan desain yang menarik. Sehingga ketika pengunjung bersantai, mengobrol, atau menikmati santapan kuliner, mereka dapat benar-benar memperhatikan desain yang ada di sekitarnya. Salah satu restoran yang saat ini sedang sangat diminati yaitu restoran Jepang. Selain dari keunikan yang dimiliki restoran Jepang tersebut, gaya hidup juga merupakan faktor penting yang mempengaruhi bentuk interior restoran sehingga dapat menarik konsumen.

Penulisan ini disusun sebagai bentuk penelitian terhadap perlu adanya kesesuaian antara gaya hidup dengan desain interior pusat perbelanjaan yang dispesifikasikan pada restoran yang menyajikan menu khas masakan Jepang. Berdasarkan permasalahan yang telah diuraikan sebelumnya, penelitian terhadap gaya hidup dan restoran Jepang ini bertujuan:

- Mengetahui fenomena masyarakat yang menuntut nilai lebih dari sebuah kebutuhan menjadi suatu tindak konsumsi yang dapat menghasilkan gaya hidup.

- Mengetahui bagaimana peran gaya hidup dalam interior restoran khususnya restoran Jepang di kota Bandung.

- Tersedianya desain area makan dengan fasilitas yang sesuai agar kebutuhan pengunjung dapat terpenuhi secara baik dan pesan desain tersampaikan.

- Dapat diketahui penerapan konsep desain interior restoran Jepang yang sesuai dengan penggambaran gaya hidup pengunjung masa kini yang menuntut hiburan, kenyamanan, dan erat kaitannya dengan selera konsumen.

- Dapat ditemukan adanya kesan tersendiri yang ditangkap oleh pengunjung setelah berkunjung ke restoran Jepang akibat dari elemen desain pada interior restoran.

\section{Kajian Literatur}

Dewasa ini, zaman terasa begitu cepat berubah, zaman dimana konsumsi gaya hidup, tanda bukan pada pasar atau system ekonomi negara, tetapi pada kapitalis multinasional yang berpusat pada pusat-pusat perbelanjaan, dan area public lainnya. Tempat-tempat area publik yang berpenampilan menarik dengan desain dan cat yang menyolok menghidupkan kota bagai cahaya yang mampu menarik laron-laron terbang mengelilingi lampu dan bersedia jatuh dalam baskom berisi air sebagai perangkap untuk meniadakan mereka. Kita sebagai laron-laron bersedia mati untuk kuasa gaya hidup konsumsi kapitalis ini. Tak heran kehidupan saat ini sangat tergantung pada kekuatan insan masing-masing dalam mengendalikannya. Bila tidak, mereka akan terjerumus pada budaya konsumerisme yang marak terjadi di berbagai wilayah. Berbekal fenomena tersebut, maka penelitian terhadap peran gaya hidup dalam mengubah lingkungan ruang public khususnya restoran, akan diutarakan dalam pembahasan tulisan ini 


\subsection{Lifestyle atau Gaya Hidup}

Aktivitas atau kegiatan manusia di saat waktu luang rutinitas kesehariannya inilah yang dapat memunculkan gaya hidup. Istilah gaya hidup sendiri pun sebenarnya digunakan untuk menunjukan identitas sosial seseorang. Setiap individu tentunya memiliki kecenderungan untuk dilihat dan melihat apa yang ad di sekitarnya. Kecenderungan inilah yang sangat berkaitan erat dengan representasi gaya hidup.

Pengertian ini didapat dari teori David Chaney yang menceritakan gaya hidup dalam bukunya yang bertajuk Lifestyle. Gaya hidup adalah perilaku seseorang yang ditunjukkan dalam aktivitas, minat dan opini khususnya yang berkaitan dengan citra diri untuk merefleksikan status sosialnya. (David Chaney,1996)

Dituturkan pula dalam sebuah artikel yang ditulis oleh Rendi D, Manusia Mall dan Gaya Hidup, bahwa suatu kegiatan konsumsi gaya hidup menjadikan diri kita manusia berbudaya yang mampu melampaui hidup yang factual. Mampu berimajinasi, tetapi sayang merepresentasikan kepentingan komersil dan politik. Kenyataan ini ditegaskan pula oleh Sugiarto dalam bukunya Posmodernisme, "Tantangan bagi Filsfat dan Adian dalam tulisannya Gaya Hidup, Resistensi dan Hasrat Menjadi”.( R Dendi,2010).

Dan ini melibatkan kondisi diri kita, baik secara fisik dan psikis kerena menggunakan sebuah cara perlu melakukan sebuah penyesuaian, bahkan perubahan diri, agar dapat menjadi terbiasa dengannya. Jadi gaya hidup tertentu, tentunya memerlukan kondisi fisik dan psikis serta seperangkat alat tertentu untuk menjalaninya.

Hal ini dikatakan Featherstone dalam bukunya "Posmodernisme dan Budaya Konsumen". Diri bukan lagi hanya berpikir tetapi diri mampu bergaya dalam konsumsinya. Hal inilah memungkinkan adanya ungkapan bahwa pemikiran Martin Heidegger "saya ada maka saya berpikir" yang merupakan kritik dari pendapat Rene Descartes "saya berpikir maka saya ada" mengalami derivatisasi menjadi "saya ada, maka saya bergaya".

Gaya hidup konsumtif menurut Jhon A Walker dalam Piliang yang menulis Imogologi dan Gaya Hidup: Membingkai Tanda dan Dunia, mempunyai beberapa sifat, yaitu gaya hidup sebagai sebuah pola, yaitu sesuatu yang dilakukan atau tampil secara berulangulang, gaya hidup mempunyai massa atau pengikut sehingga tidak ada gaya hidup yang bersifat personal, memiliki daur hidup (life-cycle), artinya ada masa kelahiran, tumbuh, puncak, surut, dan mati. Sifat ini menegaskan, gaya hidup sebagai sesuatu yang secara relative bertahan lama (durable) di dalam masyarakat konsumtif. Baik menyangkut barang, ruang dan waktu yang terus diproduksi oleh kapitalis multinasional. Kapitalis multinasional menciptakan ruang gaya hidup konsumtif ini tidak terlepas dan berhubungan timbal balik dengan pencitraan yang diproduksinya. Hubungan ini terjadi kerena gaya hidup sebagai cara manusia memberikan makna pada dunia kehidupannya membutuhkan medium dan ruang, berupa bahasa dan benda-benda, dimana citra mempunyai peran yang sangat sentral untuk mengekspresikan makna tersebut. Sedangkan citra sebagai sebuah kategori di dalam relasi simbolik di antara manusia dan dunia objek, membutuhkan aktualisasi dirinya ke dalam berbagai realitas, yang tentunya gaya hidup konsumtif termasuk di dalamnya.

Berdasarkan uraian Idi S. Ibrahim dalam buku Lifestyle Extacy, gaya hidup merupakan bentuk identitas sosial yang dijabarkan melalui 3 pokok yaitu sikap, nilai, dan cita 
rasa, bagian dari aktivitas waktu luang (konsumsi), pola yang menghubungkan individu dengan karakter sosio-struktural lain.Bentuk khusus dari perilaku gaya hidup mengacu pada bagaimana seseorang memanfaatkan hak-hak istimewanya untuk dapat menikmati sumber daya di lingkungan sekitar adalah kegiatan konsumsi.

\subsection{Teori Konsumsi}

Setiap orang atau keluarga mempunyai skala kebutuhan yang dipengaruhi oleh pendapatan. Kondisi pendapatan seseorang akan mempengaruhi tingkat konsumsinya. Makin tinggi pendapatan, makin banyak jumlah barang yang dikonsumsi. Sebaliknya, makin sedikit pendapatan, makin berkurang jumlah barang yang dikonsumsi. Bila konsumsi ingin ditingkatkan sedangkan pendapatan tetap, terpaksa tabungan digunakan akibatnya tabungan berkurang.

Demikian pula kemampuan untuk investasi, bila tingkat bunga tinggi masyarakat terdorong untuk lebih banyak menabung dan mengurangi konsumsi. Sebaliknya, bila tingkat bunga rendah orang lebih cenderung menaikkan konsumsi.Contoh sederhananya, pada saat terjadi krisis moneter tahun 1999 orang berlomba-lomba untuk menarik uangnya dari bank dengan alasan untuk memenuhi kebutuhan hidup. Untuk mengatasi hal ini pemerintah mengeluarkan kebijakan dengan menaikkan nilai suku bunga bank dengan harapan orang akan tergoda untuk menabungkan kembali uangnya ke bank karena tingkat suku bunga yang besar.

Nilai-nilai yang coba dicapai oleh arti kata konsumsi pada intinya adalah upaya atau kegiatan guna memenuhi kebutuhan. Tetapi sadarkah kita bahwa nilai yang terkandung dalam arti konsumsi tersebut kini mulai bergeser seiring dengan perkembangan apa yang sudah menjadi kebutuhan kita sebagai manusia. Hal mendasar yang dikejar tentunya nilai pemenuhan kebutuhan, maka selanjutnya setelah kebutuhan terpenuhi, manusia akan menginginkan segala sesuatu yang bersifat lebih dari "butuh" sendiri. Manusia menuntut nilai "pantas" setelah mendapatkan apa yang dibutuhkan. Nilai kepantasan ini menjadi sangat penting ketika seseorang merasa memiliki kemampuan lebih dari sekedar memenuhi kebutuhan. Tak hanya berhenti sampai pada kepantasan, nilai yang lain yang dikejar yaitu citra lebih yang ditawarkan disamping kebutuhan dan kepantasan itu. Nilai tersebut adalah segi kelebihan dan keunikan yang dimiliki suatu produk yang membedakannya dengan karakter produk lain.

Pengertian konsumsi yang memuat nilai-nilai gaya hidup pun telah dipaparkan oleh David Chaney, yaitu konsumsi sebagai tipe aktivitas sosial yang orang lakukan sehingga bisa kita pakai untuk mencirikan dan mengenali mereka, selain apa yang mereka lakukan untuk hidup. Pengertian tersebut telah cukup memuat apa yang sudah dijelaskan pada paragraph sebelumnya. Penampakan citra ini lebih dirayakan, dipuja, dan dipercaya, dan dalam hubungan dengan konsumsi gaya hidup, hal ini meniadakan kelas, struktur, dan identitas sosial, dan bisa jadi gaya hidup itu sendiri 


\subsection{Restoran}

\subsubsection{Pengertian Restoran}

Rumah makan di Indonesia disebut juga sebagai restoran. Restoran merupakan kata resapan yang berasal dari bahasa Perancis yang diadaptasi oleh bahasa inggris; "restaurant" yang berasal dari kata "restaurer" yang berarti "memulihkan". Menurut UU RI No. 34 Tahun 2000, restoran adalah tempat menyantap makanan dan minuman yang disediakan dengan dipungut bayaran, tidak termasuk usaha jenis tataboga atau catering. Pengertian restoran menurut Marsum (1994), restoran adalah suatu tempat atau bangunan yang diorganisasi secara komersial yang menyelenggarakan pelayanan yang baik kepada semua tamunya baik berupa makan dan minum.

\subsubsection{Sejarah Singkat Restoran}

Keberadaan restoran mulai dikenal sejak abad ke-9 di daerah Timur Tengah sebelum muncul di Cina. Dalam dunia Islam di abad pertengahan, terdapat " rumah makan dimana seorang dapat membeli seluruh jenis makanan yang disediakan". Rumah makan seperti ini disebutkan oleh Al-Muqaddasih seorang ahli geografi kelahiran tahun 945 masehi yang tinggal di timur tengah pada akhir abad ke 10. Dalam "Encyclopedia Britanica Volume 19 (1970)" istilah restoran pertama kali dijelaskan sebagai berikut: "The first Dining room to be known as a restaurant was opened in 1765 by A Boulanger, a soup vebdor in Paris. Refering to his soup as a restaurant ("restorative"). Boulanger inscribed on the sign above his door the latin phrase ventia ad me; voe qui stomach laboratis et ego restaurabo vos ("come to me, you with labored stomachs and I will restore you").

Keberhasilannya banyak diikuti oleh para tukang masak dan pelayan yang meninggalkan majikan masing-masing, dengan mendirikan usaha yang sama. Hal ini merupakan salah satu peristiwa penting yang mengikuti perkembangan revolusi perancis. Keruntuhan kaum bangsawan mengakibatkan mereka mebuka pikiran untuk dapat menghidupi dirinya masing-masing dengan memulai membuka usaha restoran.

\subsubsection{Restoran Jepang}

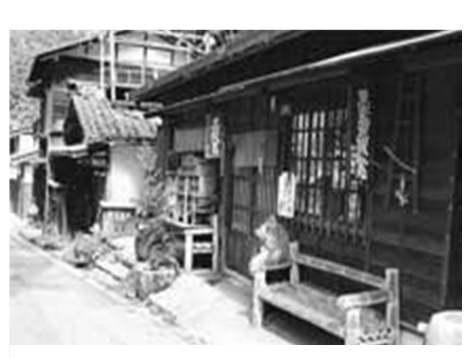

Gambar 1

Berdasarkan ungkapan dari sumber sebuah penelitian tentang "Tinjauan Interior Restoran Jepang di Jakarta", restoran Jepang yang diusahakan di tempat umum memiliki ciri-ciri tersendiri, karena setiap restoran tujuannya yaitu menarik pengunjung.Disebutkan pula pengertian dari restoran Jepang adalah tempat untuk memperdagangkan jenis masakan tradisional Jepang yang didukung dengan cara pelayanan, sajian suasana, yang diwarnai dengan kebudayaan Jepang.

Sebelum membahas restoran Jepang, baiknya apabila diulas terlebih dahulu mengenai seluk beluk arsitektural Jepang. Berdasarkan literatur yang ditulis dalam artikel "Sejarah Arsitektur", disebutkan bahwa gaya arsitektural bangunan Jepang dimulai pergerakannya sejak tahun $1600 \mathrm{M}$. 
Fasad rumah tradisional dengan bangku duduk yang didominasi bahan kayu serta pintu geser arah horizontal dan vertikal dari kayu. Zaman Edo berlangsung sekitar tahun 1600-1868 ketika Jepang di bawah pemerintahan Sogun menutup pengaruh dan hubungannya dengan dunia Barat. Keputusan itu tercermin pada pola perkembangan kota kecil di sepanjang jalur Nakasendo, salah satu di antaranya dapat dilihat di desa kuno Tsumago yang bangunan rumah tinggalnya tampak jelas didominasi corak arsitektur tradisional Jepang gaya Edo.

Beberapa jalan kecil berupa gang juga sangat menarik diikuti karena dari jalan kecil tersebut kita dapat melihat taman gaya Jepang di area halaman belakang dan depan rumah. Taman yang dilengkapi kolam batu alam dilengkapi bonsai, pancuran air dari bambu, dan kerajinan bambu lain menambah daya tarik kawasan ini.

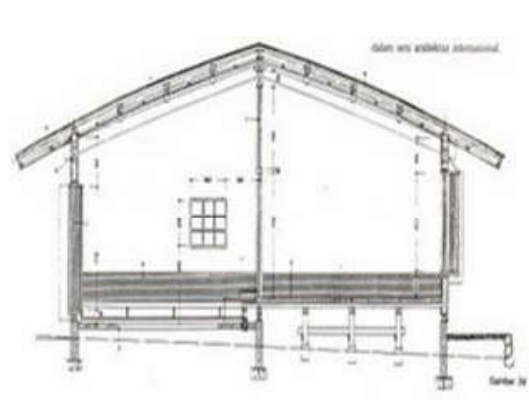

Gambar 2

Rumah tradisional Jepang berbahan kayu dan atap ditindih batu dengan aksesori fasade khas Jepang Kebanyakan bangunan utama di kawasan ini terbuat dari papan yang bila kita lihat lebih jauh menunjukkan kedekatan kehidupan Tsumago dengan pertanian, perdagangan, dan bisnis jasa yang menjadi mata pencarian utama penduduk pada masa Sogun. Atap yang ditindih batu untuk menahan agar tidak terbang tertiup angin dengan talang air pada sisi atap dan menyalurkan air ke tanah yang terbuat dari bambu juga menunjukkan kecerdikan dan pemikiran unsur teknis tukang bangunan

masa Edo. Ruangan dengan lantai tanah, tatami, dan fondasi batu alam yang ditindih bangunan bahan kayu menjadi salah satu ciri khusus.

Dengan struktur bangunan kayu berpintu geser dengan teralis kayu horizontal dan vertikal memperlihatkan gaya arsitektur tradisional jepang kuno. Tidak hanya citranya, tetapi konstruksinya pun sederhana sekali " semakin sedikit, semakin baik". Prinsip ini sudah diambil alih dalam seni arsitektur internasional.

\subsubsection{Interior Rumah Tradisional Jepang}

Sudah sejak abad ke 18 masyrakat Barat yang sudah diresapi citarasa matematika dan penalaran segala bidang kehidupan menemukan jepang sebagai negeri selera ningrat dan citarasa yang sangat cocok dengan dambaan manusia kebudayan industri yakni perpaduan antara yang eksak matematis dan yang menumbuhkan haru pada segala yang indah. Maka garis-garis dan kepolosan dinding-dinding geometrik yang menandai seluruh arsitektur jepang mereka jadikan contoh ekspresi. (lihat gambar 3). 


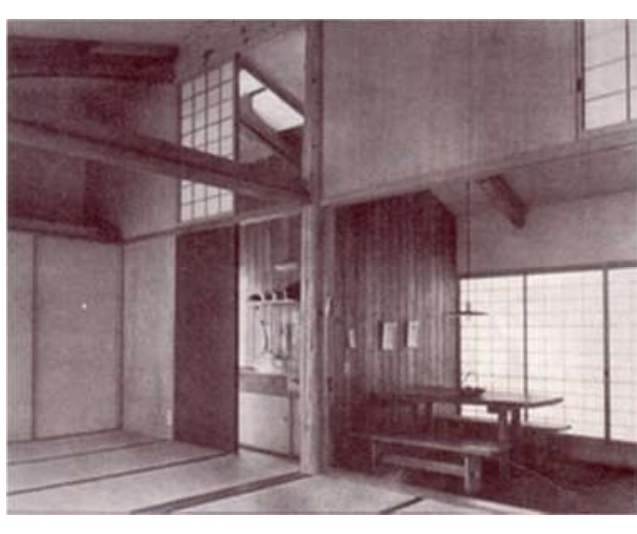

Gambar 3

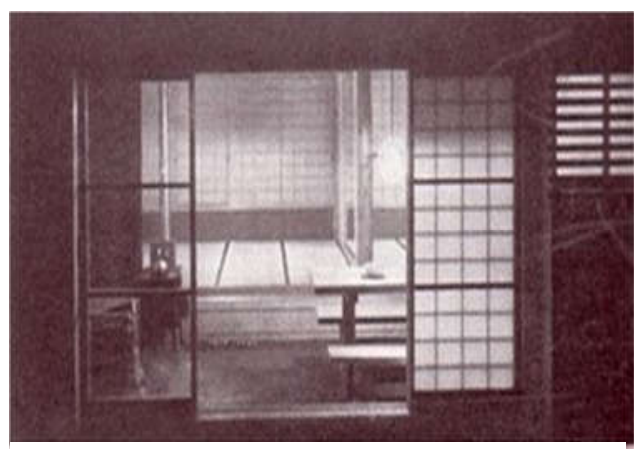

Gambar 4

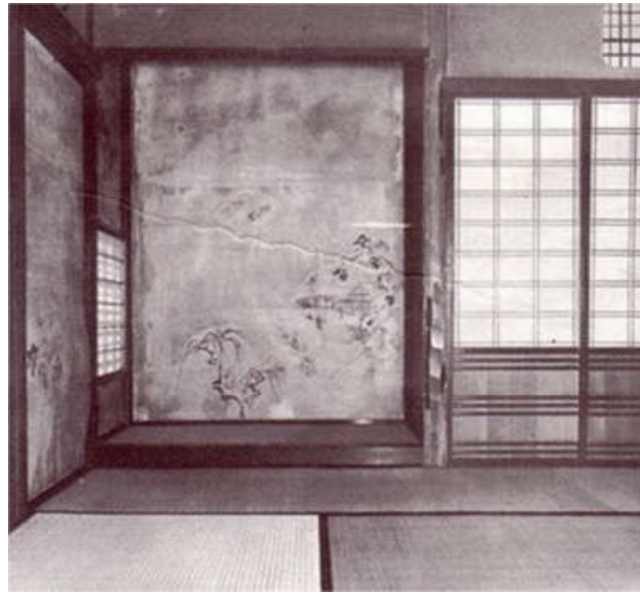

Gambar 5
Interior dan pemilihan bahan rumah Jepang Tradisional ini pun masih sama napas cita rasanya. Dinding-dinding tipis, nyaris tidak bermateri (kertas pun masih dipakai untuk dinding-dinding ruangan). Tidak aman memang dan sangat dingin di musim salju,tetapi sikap Shinto satu dengan alam tetap dimenangkan.Melalui gambar ini dan seterusnya kita dapat mempelajari dampak dan hikam asitektur tradisional Jepang yang kontemporer secara lebih terperinci. Tampaklah betapa sangat mungkinlah modernisasi dengan bahasa kontemporer, tanpa meninggalkan kekhasan pribadi pribumi.

Maka perhatikan gambar 1.5 dalam pasal 9 dari arsitektur modern tahun-tahun 20-30an. Tampaklah ciri ke Jepangan pada bangunan dan perabot rumah itu. Lihat gambar 4 Citarasa kepolosan dan kesederhanaan yang bernapas Shinto itu lebih meluas lagi sesudah Perang Dunia II, yang ternyata sedambaan dengan citarasa menusia yang baru saja dianiaya oleh wabah bahasa Meriam dan bom dunia industri. Di sini selera dan citra arjuna sangatlah jelas.

Perhatikan dinding-dinding, lantai dan langit-langit. Semua serba bidang polos, dapat dikatakan tanpa hiasan apapun. Satu-satunya "hiasan" hanyalah permainan garis-garis lurus dan bidang-bidang murni. Ditambah gambar bergaya sangat hekmat goresan, kaligrafi sajak satu saja di ruang utama dengan tokonominya. (lihat gambar 5) Dalam ruang utama, tempat penerimaan tamu, dibuat panggung kecil yang berdinding mundur sebagai tempat keramat, suatu fokus, tempat orientasi diri psikologis dalam rumah, yang disebut tokonoma. Kadang-kadang lukisan diganti dengan yang lain, atau dipajang satu syair dengan seni kaligrafi indah, demi percakapan tenbtang puisi atau tukar-menukar kearifan, pengetahuan budaya. Berikut adalah bentuk sekian unsur kontras bermain dalam melodi tesa-antitesa-sintesa:

- Luar dan Dalam.

- Garis bidang geometrik lurus-datar-ketat dan bentuk-bentuk organik luwes.

- Kebersihan polos netral warna di dalam dan yang serba variasi warna-warni di luar. 
Denah Rumah tradisional Jepang dengan pembagian ruang yang berbentuk sederhana yaitu kotak atau persegi. Manusia modern abad ke 20 memang sedang gandrung pada segala hal yang geometris. Tetapi geometriks yang menyentuh kalbu hati. Dan apa yang menjadi kenyataan budaya arsitektur dari seorang tokoh dan perintis arsitektur modern, Mies Van der Rohe? Mies van der Rohe merumuskannya demikian: "semakin sedikit semakin baik". Tetapi perumusan yang menjadi tersohor itu praktis sudah dikerjakan berabad-abad oleh orang-orang yang berjiwa Shinto dan Budha Zen.

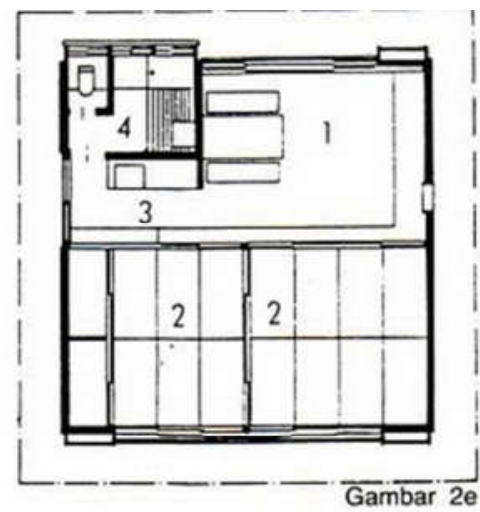

1. Ruang makan.

3. Sudut dapur.
2. Ruang 2 tatami (R. Keluarga \& R. Tidur)

4. Kamar mandi-WC.
Bentuk dan pola penataan ruangan dari beberapa restoran yang memperdagangkan masakan Jepang diungkapkan dengan model tradisional Jepang, meskipun pada dasarnya bangunan yang dijadikan restoran tersebut memiliki eksisting yang tidak disediakan secara arsitektural Jepang. Hal ini pun nantinya akan dibahas dalam kaitannya dengan pengaruh gaya hidup terhadap bentuk bangunan dan tata ruang di dalamnya. Sebelum membahas tentang interior restoran Jepang yang dipengaruhi oleh nilai-nilai yang terkandung dalam gaya hidup, baiknya akan dibahas terlebih dahulu mengenai hakikat restoran Jepang itu sendiri.pembahasan akan diulas berdasarkan penelitian yang sudah ada.

\section{Gambar 6}

\subsubsection{Pelayanan Restoran}

Restoran Jepang ini memiliki cirri khas tersendiri dalam tata cara pelayanannya. Pola pelayanan sangat mencerminkan karakter dari tradisi masyarakan Jepang ketika sedang melayani tamu-tamunya. Berdasarkan keterangan sumber, pola pelayanan restoran Jepang dibedakan menjadi 3 jenis pelayanan, yaitu :

- Swalayan

- Antrian

- Sajian

\section{a. Pelayanan Swalayan}

Merupakan salah satu cara pelayanan restoran dengan sistem melayani diri sendiri. Cara ini dimulai dengan pengunjung memesan terlebih dahulu menu tertentu yang dikehendaki kepada pelayan restoran. Selanjutnya pelayan restoran akan menghidangkan alat masak serta bahan makanan dalam keadaan mentah ke meja pengunjung. Setelah itu, pengunjung secara langsung dapat memasak sendiri di atas meja makan yang telah dilengkapi dengan peralatan masak yang sudah disediakan. Salah satu contoh makanan yang disajikan dengan cara ini yaitu shabu-shabu atau sukiyaki dan lain-lain. 


\section{b. Pelayanan Antrian}

Dengan cara ini pengunjung pengunjung mengambil nampan lalu antri menuju counter. Di area counter tersebut pengunjung bebas memilih makanan yang dihidangkan ke dalam piring makan atau ke tempat makanan lain yang diletakkan di atas nampan. Setelah memilih makanan, maka pengunjung akan menuju tempat pembayaran atau kasir, pelayan kasir akan menghitung pembayaran berdasarkan jumlah makanan yang diambil. Setelah selesai melakukan pembayaran, pengunjung dapat langsung memilih tempat duduk untuk menyantap makanannya yang sudah siap saji.

\section{c. Pelayanan Sajian}

Cara ini biasa disebut cara yang istimewa dalam hal pelayanan, karena pengunjung dilayani dari memesan menu masakan hingga tahap dimasakkan di tempat sampai disajikan oleh pelayan restoran tersebut. Prosesi pelayanan ini juga dilakukan di ruangan tertentu.Salah satu contoh ruangan yang digunakan untuk jenis pelayanan ini adalah ruang tatami atau ruang tepanyaki.

\subsubsection{Kaitan Gaya Hidup, Konsumsi, dan Restoran}

Gaya hidup, merupakan suatu hal yang sangat menarik untuk diamati, dipelajari, dan juga direnungkan. Berdasarkan pengamatan, gaya hidup secara tidak sadar telah membawa dan dapat mengemudikan diri kita sejak kita membuka mata di saat pagi dan menutup mata di malam hari. Gaya hidup ini menjadi begitu melekat dalam diri setiap individu. Namun kemudian muncul pertanyaan, bagaimana gaya hidup ini dapat menjadi bagian dari apa yang kita lakukan sehari-hari.

Mengutip karya A.B Susanto dalam buku "Potret-Potret Gaya Hidup Metropolis", gaya hidup yang berasal dari berbagai sisi dapat dikaitkan dengan citra diri, trend yang tengah berlangsung, human interest, dan juga krisis yang melanda negara kita. Citra diri dapat diartikan sebagai bagaimana seseorang memandang dirinya sendiri. Atau mungkin diartikan sebagai bagaimana persepsi orang lain terhadap seseorang. Berdasarkan bagaimana seseorang ingin dipersepsikan oleh orang lain inilah salah satu faktor terpenting yang mempengaruhi gaya hidup seseorang. Seseorang tersebut akan memiliki frame of reference yang dipakai dalam bertingkah laku yang terepresentasi dalam minat, aktivitas, dan opininya.

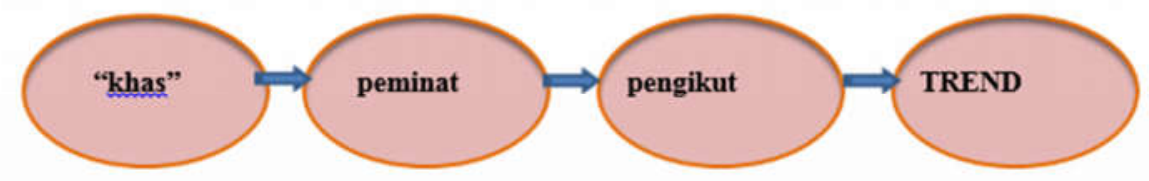

Bagan 1 Alur Terbentuknya Tren Gaya

Berdasarkan pertimbangan itulah dapat disebutkan pengertian dari gaya hidup itu sendiri. Gaya hidup adalah perilaku seseorang yang ditunjukkan dalam aktivitas, minat dan opini khususnya yang berkaitan dengan citra diri untuk merefleksikan status sosialnya. Hasilnya, masyarakat memiliki sebuah struktur sosial yang melibatkan status sosial dan peran sosialnya. Dapat disimpulkan bahwa gaya hidup tidak selalu ditentukan oleh faktor didalamnya. Tetapi justru gaya hidup muncul karena keinginan individu yang bertujuan untuk 
memproyeksikan citra dirinya atau tuntutan yang terjadi di masyarakat dapat lebih menentukan bagaimana bentuk gaya hidupnya.

Adapun uraian tentang gaya hidup yang lebih spesifik dituangkan berdasarkan Sobel M,E yang mengatakan bahwa gaya hidup dapat berarti setiap cara kehidupan yang khas dan karena itulah cara tersebut dapat dikenali. Dengan kata lain, bahwa gaya hidup untuk dapat melihat dan dilihat membutuhkan nilai yang berbeda agar nampak mencolok untuk dijadikan sebagai tonggak eksistensi diri. Bila digambarkan dalam alur bagan,maka sesuatu yang "khas" tersebut muncul sebagai akibat adanya trend di akhir karena peran peminat dan juga para pengikutnya. Dapat ditafsirkan bahwa golongan peminat dalam hal ini merupakan golongan menengah ke atas yang memiliki kemampuan untuk mengkonsumsi produk dengan nilai khas yang biasa ditaksir dengan harga diatas rata-rata. Seperti contohnya kalangan eksekutif, public figure, dan lain sebagainya. Mereka yang berada di kalangan tersebut membentuk adanya kelompok yang dapat dikatakan sebagai "follower". Para follower ini menilai bahwa dengan mengikuti tampilan gaya para kalangan menengah ke atas, maka mereka pun beranggapan untuk meningkatkan citra dirinya agar dapat disejajarkan dengan kalangan tersebut. Semakin banyak adanya follower atau pengikut, maka akan terbentuklah sebuah trend yang menjadi tonggak munculnya gaya hidup.

Terdapat pula pendapat lain yang dapat diajadikan acuan dalam menelaah kandungan gaya hidup, yaitu gaya hidup yang diutarakan oleh Idi S Ibrahim. Dalam bukunya, diutarakan bahwa gaya hidup diartikan sebagai bentuk identitas sosial. Simbol identitas yang menggambarkan status memang tidak bias dielakkan dalam pola pergaulan. Apalagi bagi sebagian besar orang golongan penting yang selalu mendapat sorotan masyarakat. Kelas sosial dan status sosial akan berjalan secara bersamaan dan secara otomatis akan saling melengkapi.

\subsubsection{Gaya Hidup Konsumsi}

Bentuk khusus dari perilaku gaya hidup mengacu pada bagaimana seseorang memanfaatkan hak-hak istimewanya untuk dapat menikmati sumber daya di lingkungan sekitar. Berdasarkan hal ini maka gaya hidup sangat berkaitan dengan aktivitas konsumsi.

Konsumsi menurut David Chaney : "Tipe aktivitas sosial yang orang lakukan sehingga bisa kita pakai untuk mencirikan dan mengenali mereka, selain apa yang mereka lakukan untuk hidup" (David Chaney,1996)

Berdasarkan teori yang disebutkan, dapat dianilisis bahwa nilai yang terkandung dalam konsumsi tidak hanya sekedar memenuhi kebutuhan tetapi juga terdapat nilai yang lebih daripada itu. Setelah manusia dapat memenuhi kebutuhannya maka nilai yang konsumsi yang dituntut setelah itu adalah kepantasan. Kebutuhan dan kepantasan telah terpenuhi, maka nilai lebih yang dicari adalah keunikannya.

\subsubsection{Konsumsi Makanan sebagai Gaya Hidup}

Makan dalam masyarakat tradisional hanyalah aktivitas pengisi perut untuk hidup. Disebutkan berdasarkan hirarki Abrham Maslow tentang pengertian makan : "makan merupakan kebutuhan paling dasar dari manusia,yaitu kebutuhan fisik." Nilai konsumsi yang paling gencar ditawarkan adalah kebutuhan makan. Namun, ketika makan bukan sekedar alat 
penyambung hidup, maka makan merupakan sebuah alat aktualisasi diri. Berdasarka pernyataan tersebut, makan kini tak hanya sekedar kegiatan memasukkan makan ke dalam tubuh, melainkan sebagai cara manusia untuk dapat hidup bersosialisasi di lingkungan masyarakat juga. Dalam perkembangan lebih lanjut, makan menjadi suatu kegiatan yang penuh dengan makna. Bagaimana fenomena ini terjadi ? Berdasarkan penelitian yang terjadi saat ini, makan merupakan kegiatan yang penuh makna, diantaranya :

1. Remaja / pasangan kekasih : makan merupakan ritual agung yang penuh kemesraan

2. Pemimpin politik : makan bisa diartikan sebagai penggalangan massa

3. Para eksekutif : makan artinya lobbying

4. Seniman : makan untuk nongkrong dan membentuk relasi

\section{A. Konsumsi Makan Dalam Restoran Sebagai Bagian Gaya Hidup}

Restoran menjadi wadah utama guna memenuhi selera atau cita rasa pasar akan kebutuhan makan. Sesuai dengan pengertian restoran itu sendiri, merupakan tempat yang memperdagangkan masakan dan minuman, sifatnya menarik pengunjung sebanyak mungkin, melalui citra rasa masakan yang diperdagangkan.

Tetapi kini, restoran tersebut telah menjadi wadah yang dinilai sebagai daya tarik utama konsumen dalam hal menikmati waktu luang secara santai. Oleh karenanya lokasi restoran lebih sering dijumpai di tempat-tempat strategis di pertengahan kota atau dekat dengan daerah wisata yang menghadirkan pula pemandangan yang dapat menyejukkan mata.

Selain bersantai dengan gaya, sebenarnya terdapat motivasi lain dibalik kegemaran orang mengunjungi restoran guna bersantai, yakni sifat to see and to be seen. Karena di restoran ini berbagai jenis manusia penting atau yang dianggap penting wajib untuk sering bertandang dan bercengkrama di area public seperti restoran ini. Hal ini sangat dianggap wajar sebagai suatu fenomena yang kerap ada di masyarakat, mengingat manusia adalah makhluk sosial. Sehingga sangat wajar jika secara naluriah mereka ingin bersosialisasi.

Hal inilah yang dijadikan subjek penelitian terhadap dampaknya pada bentuk lingkungan yang dijadikan wadah bersosialisasi mereka. Dalam konteks ruang public dan aktivitas makan yang tak lagi menjadi sekedar kebutuhan, maka restoran merupakan wadah yang paling sesuai untuk merepresentasikan gaya hidup yang ada saat ini.

\section{B. Studi Kebutuhan Restoran Jepang}

Dalam studi kasus yang saya ambil, restoran Jepang sebagai salah satu restoran yang berhasil menarik penggemar sekian banyak hingga muncullah sutu trend yang baru. Salah satu contohnya trend makan sushi. Hal tersebut secara ringkas dapat dijelaskan penyebabnya karena masyarakat selalu mencari nilai yang khas dari setiap produk yang ditawarkan. Sushi dianggap sebagai makanan yang berbeda dibanding makanan pada umumnya yang dijual di restoran biasa. Cita rasanya yang sangat mencerminkan Negara asalnya membuat sushi kemudian digemari oleh masyarakat. Karena bahan sushi yang susah didapat, maka harganya pun tidak seperti harga makanan biasa yang relative terjangkau. Hal ini membuat sushi 
dipandang sebagai makanan yang memiliki ciri khas sekaligus dinilai eksklusive. Hal seperti inilah yang dapat menciptakan kemunculan tren gaya hidup.

Bila dilihat dari segi interior, restoran yang memperdagangkan sushi atau dinamakan sebagai restoran Jepang memiliki nilai keunikan tersendiri di mata masyarakat Indonesia. Citra arsitektural khas Jepang yang ditawarkan menjadi daya tarik konsumen. Sebagai sebuah kota yang banyak dikunjungi oleh domestic maupun asing, maka pengusaha sebuah restoran Jepang di Bandung harus dapat merebut konsumen yang berasal dari berbagai kalangan. Sehubungan dengan penampilan restoran yang menjual hasil kebudayaan bangsa Jepang, perlu adanya beberapa pertimbangan untuk mewujudkan suasana dan cita rasa Jepang dalam restoran tersebut.

Salah satu yang mendukung penampilan tersebut adalah peletakan elemen dekoratif yang memegang suatu ciri kebudayaan Jepang sebagai daya tarik pengunjung dan kesesuaian suasana. Terdapat beberapa pertimbangan guna diperhatikan oleh pendesain ruangan, yaitu faktor yang dibutuhkan dalam penciptaan suasana:

\section{a. Faktor Penglihatan.}

Factor ini tidak hanya desain interiornya saja yang diperhatikan, tetapi juga keadaan pencahayaan yang dikandung dalam ruangan itu sendiri. Salah satu faktor yang banyak mempengaruhi penglihatan adalah pengaturan cahaya. Kebutuhan utama dari pengaturan cahaya adalah untuk menyediakan suatu tingkatan pencahayaan yang cukup memadai dan disesuaikan dengan bermacam-macam kegunaan secara baik dan efisien.

\section{b. Faktor Penciuman}

Faktor ini tergantung dari kualitas udara atau pada pengaturan udara dalam ruangan itu sendiri. Dalam hal ini pengaturan udara harus dirancang dengan baik yang bias menjamin pengunjung tidak terganggu oleh bau-bau yang tidak diinginkan. Tetapi dalam keadaan lainnya bau-bauan tertentu justru dapat menarik perhatian pengunjung restoran. Jelaslah bahwa factor penciuman mempunyai arti yang khusus yang bias mempengaruhi suasana dalam restoran. Seperti halnya beberapa restoran Jepang menggunakan pelayanan sendiri oleh pengunjungnya sehingga dapat memasak sendiri menu yang dipesannya.

\section{c. Faktor pendengaran}

Suatu pengelaman membuktikan bahwa setiap pengunjung restoran membutuhkan suatu latar belakang bunyi-bunyian atau lebih dikenal dengan musik. Dalam hal in music memeiliki pengaruh yang besar terhadap suatu ruang restoran, yang ternyata dapat menghindari kesan sepi. Penggunaan music dalam suatu restoran sebagai pengantar makan para pengunjung dapat mempengaruhinya. Hal ini bias dibuktikan dari kesan interiornya dan ditunjang ddeengan latar belakang music. Restoran Jepang yang banyak dijumpai di Bandung, rata-rata menggunakan latar belakang musik di negrinya, sebagian besar terdiri dari jenis music instrumental, alasannya hanya untuk menghindari kebosanan para pengunjung.

\section{d. Faktor Sentuhan}

Masalah ini mencakup segala sesuatu yang bias disentuh oleh organ tubuh kita seperti contohnya kenyamanan dalam posisi duduk ketinggian meja yang pas, dan lain sebagainya. 


\section{e. Faktor Rasa}

Masalah ini menyangkut langsung factor utama yang dihadirkan restoran yaitu hidangan makanan. Mutu dan rasa dari makanan benar-benar dinilai langsung oleh pengunjung restoran.

\section{Metoda Penelitian}

Proses penelitian terhadap topik yang akan dibahas ini menggunakan metode kualitatif dengan pendekatan observasi, wawancara, survey, dan juga studi literature. Observasi/penelitian dilakukan dengan survey langsung ke lapangan secara fokus pada objek penelitian. Dalam hal ini yaitu manusia (pengunjung), desain area restoran Jepang, serta elemen interiornya secara keseluruhan. Hal yang ditinjau adalah kesesuaian tema perancangan area makan dengan citra yang ingin ditampilkan restoran itu sendiri berdasarkan gaya hidup masyarakat di Bandung. Sistem wawancara yang dilakukan yaitu dengan mengambil objek wawancara pada lokasi penelitian. Studi literatur yaitu dalam hal ini penelitian didasarkan pada studi literatur yang ada seperti dari artikel pada buku. Berikut adalah bagan alur penelitian yang digunakan:

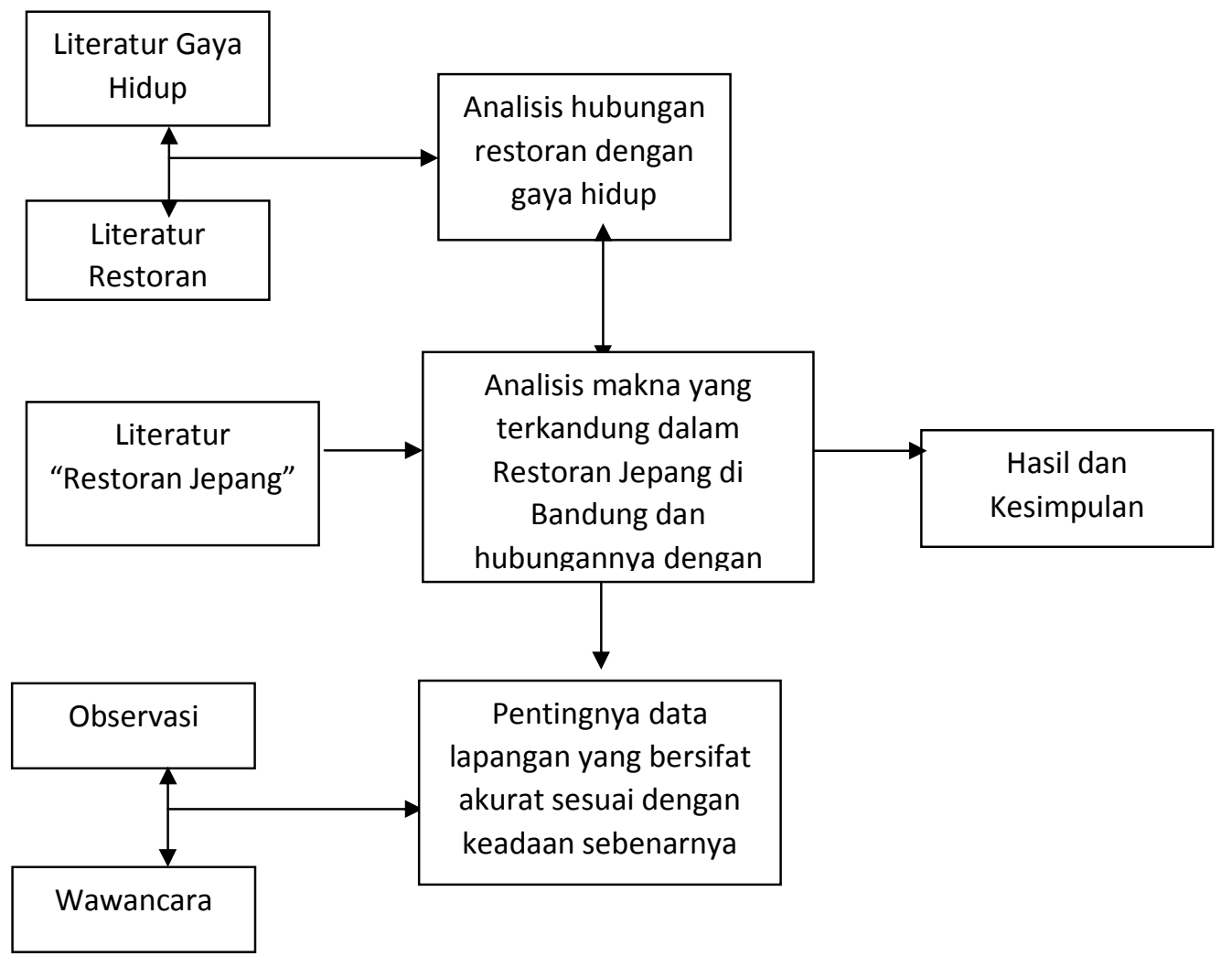

Bagan 2 
Selain menggunakan sumber literatur, penelitian dilakukan melalui proses survey secara langsung ke beberapa lingkungan yang berkaitan. Cara yang dilakukan yaitu mewawancarai beberapa pihak yang berperan dalam lingkungan yang dijadikan objek penelitian. Selanjutnya, meninjau langsung mengenai detail area yang dapat dijadikan fokus penelitian. Melalui cara ini, penelitian dapat terlaksana dengan baik, dan hasilnya dapat tersampaikan secara rinci tentang apa yang menjadi permasalahan dan penyelesaiannya. Selanjutnya akan dibahas secara berurutan berdasarkan hasil penelitian yang didapat tentang seberapa besar pengaruh gaya hidup masyarakat dapat mempengaruhi bentuk serta tata ruang interior dalam restoran Jepang khususnya di daerah Bandung.

\section{Hasil Temuan Berdasarkan Analisis Gaya Hidup Pengunjung Restoran Jepang}

Berdasarkan pada hasil survey ke restoran Jepang Sushi Tei di Bandung, maka didapatkan data pengunjung beserta jenis pengunjung yang menjadi konsumen restoran tersebut. Dari segi kualitas, maka pengunjung yang datang ke restoran Jepang ini adalah pengunjung yang berasal dari golongan menengah ke atas, baik pengunjung dalam maupun luar negeri.

Pada umumnya pengunjung yang datang terdiri dari bangsa Indonesia yang terdapat keturunan Cina yang telah lama menetap di Indonesia. Beberapa juga terkadang datang pengunjung berkebangsaan asing seperti Belanda, Amerika, Jerman, Australia yang rata-rata memiliki latar belakang kebudayaan barat. Sedangkan pengunjung yang merupakan pribumi Indonesia merupakan kalangan berada yang terdiri dari kalangan eksekutif, entertainer, dan kalangan lain yang biasa berada dalam kehidupan serba mewah.

Apabila pengunjung restoran ditinjau dari segi kuantitas, maka jumlah pengunjung paling besar merupakan pengunjung yang berasal dari Indonesia. Dilihat dari segi gender, pengunjung pria lebih banyak disbanding pengunjung wanita. Hal ini dikarenakan restoran Jepang pun termasuk ke dalam restoran yang sering dijadikan tempat pertemuan penting seperti rapat, negosiasi, dan lain sebagainya, yang sebagian besar pelakunya adalah kaum pria. Bila dilihat dari segi usia, pengunjung yang datang untuk menikmati hidangan di restoran jepang ini lebih banyak berasal dari golongan usia dewasa 20 tahun keatas disbanding mereka yang berusia 20 tahun ke bawah.

Golongan pengunjung seperti inilah yang berpotensi memegang peran gaya hidup yang dapat berpengaruh pada bentuk pemilihan interior yang disesuaikan tak hanya dengan kebutuhan namun lebih dari sekedar nilai tersebut. Dapat dikatakan bahwa kalangan seperti inilah yang berperan menjadi trend setter dan pada akhirnya muncul sebuah gaya hidup baru berikutnya dan seterusnya.

\subsection{Karakteristik Suasana Interior Restoran Jepang di Bandung}

Karakteristik suasana dalam ruangan adalah hal yang sangat diperhatikan dalam upaya pembentukan ciri khas yang membedakannya dengan restoran lain. Suasana tersebut dapat terwujud karena adanya kemampuan pendesain ruang yang bisa menciptakan gagasan 
desain untuk kemudian dilaksanakan melalui para tukang-tukang ahli, maka terbentuklah suasana yang dikehendaki. Selain daaripada hal tersebut, desainer pun harus benar-benar memahami dan menguasai apa yang menjadi kebutuhan pasar akan selera dalam mengkonsumsi sumber daya di sekelilingnya.

Suasana interior restoran merupakan perkembangan dari tema perancangannya. Sedangkan tema tersebut pun berangkat dari nama dan jenis restoran. Salah satu contoh karakteristik yang harus muncul dalam interior restoran Jepang tidak lain yaitu adanya suasana yang serupa seperti kita memasuki sutu ruangan bernafaskan budaya Jepang. Suasana interior restoran yang penuh dengan kesederhanaan budaya tradisional Jepang dihadirkan dalam bentuk desain modern dengan citra yang memperlihatkan gaya arsitektur tradisional jepang kuno. Tidak hanya citranya, tetapi konstruksinya pun sederhana sekali "semakin sedikit, semakin baik". Prinsip ini pun sudah diambil alih dalam seni arsitektur internasional.

\subsection{Pembahasan Interior Restoran Jepang Sushi Tei di Bandung yang Dipengaruhi Gaya Hidup}

Restoran Sushi Tei Bandung termasuk ke dalam jaringan restoran sushi Tei International yang memulai debutnya pada tahun 1994. Terletak di Jalan Raya Sumatra no. 9, Sushi Tei mampu menarik perhatian masyarakat untuk berkunjung ditengah lokasinya yg berdekatan dengan restoran lain. Bentuk interior yang diilhami dari budaya trdisional Jepang dapat terlihat sangat jelas. Selain itu bentuk mdern yang dipengaruhi gaya hidup masyarakat saat ini diterapkan dalam bentuk kolaborasi yang unik sehingga mengundang pengunjung untuk datang.

\subsubsection{Tata Pengaturan Ruang}

Layout area pengunjung secara garis besar dimulai dari main entrance yang terdapat meja receptionist. Selanjutnya pengunjung memasuki area makan melalui alur sirkulasi yang menghantarkan dari area receptionist. 

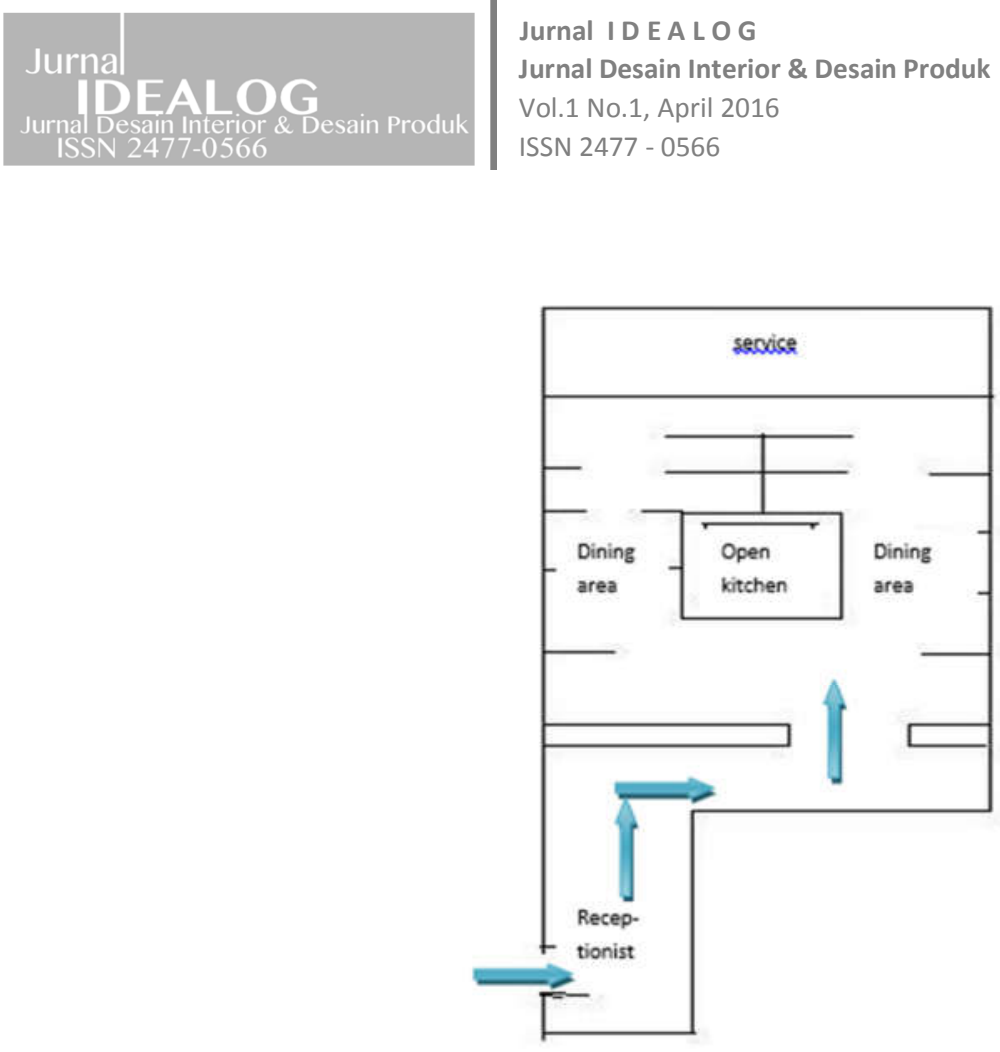

Gambar 8. Sirkulasi \& Layout Ruang Sushi

Pada area entrance hall, diterapkan pintu sekligus berfungsi menjadi jendela yang berbahan material kaca yang diletakkan secara vertikal ke atas. Hal ini menimbulkan kesan ruang yang tinggi dan mewah. Di dalamnya terdapat receptionist table yang berfungsi untuk menerima pengunjung yang datang.Bila terdapat pengunjung yang masuk daftar waiting list, pengunjung akan ditampung sementara pada area ini tanpa terlihat dari area pengunjung yang makan.

Masuk menuju area makan pengunjung akan disambut oleh pelayan dan konsep tata ruang yang unik dengan dapur terbuka.Di area ini cara penyajiannya cukup istimewa, karena sistemnya pengunjung tinggal mengambil makanan yang beredar memutar sepanjang meja dapur terbuka tersebut.

\subsubsection{Elemen Penyusun Interior Restoran}

Elemen penyusun ruangan terdiri dari elemen yang sifatnya transparan seperti kaca dan pilar-pilar yang digunakan sebagai partisi. Hal ini menghindari kesan ruangan yang sempit. Karena pada dasarnya bentuk eksisting bangunan tidak terlalu besar.

Terdapat hal menarik yang terdapat pada elemen penyusun ruang ini, yaitu kombinasi pilar-pilar dengan bambu buatan di dalam kaca sebagai salah satu elemen dekoratif yang dapat menarik perhatian pengunjung. Sebagian besar bahan material menggunakan kayu solid maupun manufacture board. Hal ini disesuaikan dengan bentuk rumah tradisional Jepang dengan bangku duduk yang didominasi bahan kayu serta pintu geser arah horizontal dan vertikal dari kayu. 


\subsubsection{Sistem yang Berada pada Interior Restoran karena Pengaruh Gaya Hidup}

Pada dasarnya bangunan arsitektur tradisional Jepang sangat menjunjung tinggi nilai kesederhanaan. . Tidak hanya citranya, tetapi konstruksinya pun sederhana sekali " semakin sedikit, semakin baik". Semua serba bidang polos, dapat dikatakan tanpa hiasan apapun. Satu-satunya "hiasan" hanyalah permainan garis-garis lurus dan bidang-bidang murni. Bentuk geometris yang menguasai ruangan di dalamnya pun berasal dari kesederhanaan bentuk dasar rumah tradisional Jepang dengan pembagian ruang yang berbentuk sederhana yaitu kotak atau persegi.

Penerapan kesederhanaan tersebut dikolaborasikan dengan style yang ada saat ini. Berikut penjelasan mengenai sistem yang bekerja di dalam restoran akibat pengaruh gaya hidup.

a) Sistem Pencahayaan

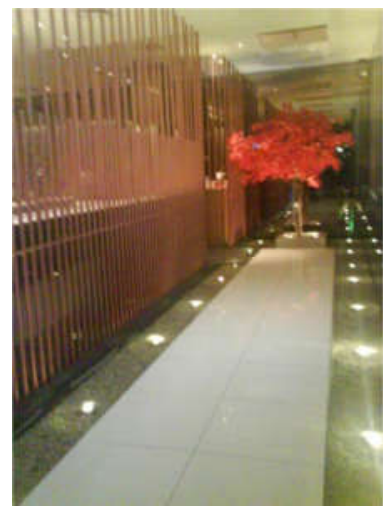

Interior bangunan arsitektur Jepang memiliki konsep yang sangat sederhana terhadap pencahayaannya. Sedangkan untuk menarik pengunjung, sebuah restoran harus memenuhi selera konsumennya akan kebutuhan style-nya. Sistem pencahayaan yang artificial akan lebih sesuai apabila diterapkan di area meja makan guna memberikan suasana santai sekaligus dapat memanjakan mata para pengunjungnya.sistem pencahayaan artificial ini diterapkan pada interior sushi tei dengan menggunakan spot light yang terletak pada pilar-pilar kayu. Seperti yang terlihat pada gambar di samping.

\section{Gambar 9 Letak Spotlight}

b) Sistem Penentuan Material

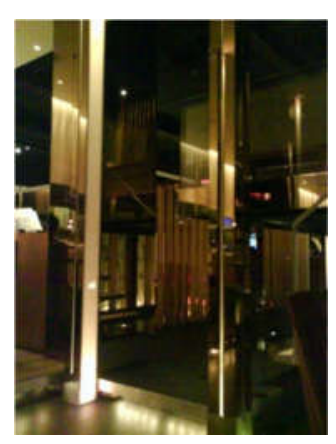

Sebagian besar material menggunakan bahan alami seperti kayu dan keramik bebatuan. Hal ini disesuaikan dengan hakikat budaya Jepang yang erat kaitannya dengan alam. Sebagai aksen untuk menambah nilai estetik sebagai tuntutan sebuah gaya hidup, maka diterapkan material yang sifatnya jauh berbeda dengan bahan kayu atau bahan alami lainnya. Sushi Tei menerapkan bahan logam stainless sebagai aksen ruangan. Hal ini meningkatkan nilai eksklusif sebuah ruangan interior. Sifat yang disesuaikan dengan tampilan gaya hidup pengunjung inilah yang menjadi tolak ukur guna menarik pengunjung.

Gambar 10. Material memberi kesan Eksklusif 


\section{Kesimpulan}

Berdasarkan hasil penelitian yang telah dilakukan, maka dapat disimpulkan dalam beberapa pokok tentang adanya pengaruh gaya hidup terhadap interior restoran Jepang di kota Bandung. Berikut pokok simpulannya :

1. Gaya hidup ada berdasarkan fenomena yang terjadi pada pribadi manusia dalam memenuhi nilai dari sekedar kebutuhan,yakni kepantasan, keunikan, dan pada akhirnya muncul sifat melihat dan ingin dilihat. Tujuan manusia memanfaatkan hal-hal di sekitarnya ketika bersantai di area makan atau restoran yaitu guna menunjukkan identitas sosial yang mencerminkan bentuk aktualisasi diri (bagian dari gaya hidup).

2. Restoran menjadi salah satu area publik yang berperan dalam merepresentasikan sifat gaya hidup, karena aktivitas di dalam restoran yang kini telah bergeser sebagai wadah penangkap citra diri melalui berbagai kegiatan yang dilakukan selain makan.

3. Bentuk interior restoran Jepang memiliki karakter unik khas budaya Jepang yang kini dikombinasikan dengan selera tren pasar sehingga menarik pengunjung sebagai salah satu penyebab meningkatnya nilai konsumsi.

4. Nilai keunikan, kekhasan, serta sifat different ditampilkan dalam elemen interior restoran Jepang yang dapat meningkatkan minat konsumsi masyarakat sebagai pengaruh dari gaya hidup itu sendiri.

5. Kondisi area makan nyaman dengan sistem dan pola tata ruang yang lebih dinamis diterapkan dalam interior restoran Jepang yang dapat mendukung perasaan pengunjung dalam memenuhi kebutuhan gaya hidupnya.

6. Penerapan desain pada restoran Jepang disesuaikan dengan nilai keunikan budaya Jepang dan juga karakteristik selera pengunjungnya berhasil menciptakan nilai tersendiri yang melekat di kalangan masyarakat sehingga mengakibatkan timbulnya tren restoran Jepang di Indonesia khususnya di Bandung.

\section{Daftar Pustaka}

[1] David, Chaney., 1996. Life Style:Sebuah Pengantar Komprehensif. Jalasutra, Yogyakarta.

[2] Susanto, A.B., 2001. Potret-Potret Gaya Hidup Metropolis. Kompas, Jakarta.

[3] Enggel, JF. Blackwell, RD Miniard PW., 1995. Perilaku Konsumen Jilid 2. Binarupa Aksara, Jakarta.

[4] Itoh, Teiji., 1963. The Roots of Japanese Architecture. A Weathermark Edition, Tokyo.

[5] Elly., 1987. Tinjauan Interior Restoran Jepang di Jakarta. Skripsi tidak diterbitkan. Bandung. ITB

[6] Eka, Sabirin., 2005. Kenapa Remaja Doyan Berbelanja?. www.kompSas.com. Diakses 10 Mei 2010

[7] Arsitektur Tradisional Jepang, 2009, rurucoret.blogspot.com. Diakses 14 Mei 2010

[8] Dendi, R., Manusia Mall dan Konsumsi Gaya Hidup, 2009, rurucoret.blogspot.com. Diakses 14 Mei 2010 